\title{
Характеристика структурно-функціонального стану кісткової тканини у хворих похилого та старечого віку з переломами вертлюгової ділянки стегнової кістки
}

\begin{abstract}
Мета роботи: проаналізувати структурно-функціональний стан кісткової тканини (СФСКТ) у людей похилого та старечого віку та структуру переломів вертлюгової ділянки стегнової кістки (ВДСК) на грунті порушень мінеральної щільності кісткової тканини (МЩКТ).

Матеріали і методи. У роботі проаналізовано результати обстеження 98 хворих похилого та старечого віку, які перебували на лікуванні в КНП “Івано-Франківська обласна клінічна лікарня Івано-Франківської обласної ради” впродовж 2008-2018 рр.

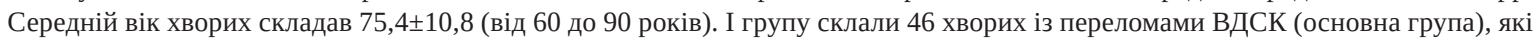
отримали низькоенергетичні пошкодження. До контрольної групи увійшли 52 особи, котрі обстежувались 3 приводу захворювань опорно-рухового апарату. Усім хворим виконано двохенергетичну рентгенівську абсорбціометрію (DEXA) поперекового відділу хребта. У хворих I групи визначали тип перелому за класифікацією AO/ASIF.

Результати досліджень та їх обговорення. Порушення показників МЩКТ виявлено у 72 (73,5 \%) хворих обох груп. У хворих I групи максимальний показник зниження кісткової маси Т індекс становив -3,5, у хворих II групи - Т= -2,8. У хворих похилого віку I групи середній показник Т індексу становив -1,32, а у хворих старечого віку I групи - -1,86. У хворих похилого віку II групи середній показник Т становив -0,85, а у хворих старечого віку II групи - -1,33. Серед хворих I групи, в яких при денситометрій виявлено порушення структури кісткової тканини, більшість переломів за класифікацією AO/ASIF були складними, тобто уламкові зі зміщенням, і становили 39(84,8 \%) випадків. Порушення показників МЩКТ в обстежених хворих похилого та старечого віку та висока частота складних уламкових переломів вказують на необхідність подальшого вивчення СФСКТ та оптимізації лікування у хворих цієї вікової категорії.
\end{abstract}

Ключові слова: мінеральна щільність кісткової тканини; перелом вертлюгової ділянки стегнової кістки; структурно-функціональний стан кісткової тканини.

Постановка проблеми і аналіз останніх досліджень та публікацій. Особлива демографічна тенденція до прискореного глобального старіння населення планети в XXI столітті характерна і для жителів України [1]. Наша країна входить в тридцятку “найстаріших" країн світу [1-3]. За інформацією міністерства соціальної політики України, у 2015 р. частка осіб віком понад 60 років становила 21,8 \%, а людей віком понад 65 років - 15,5 \% від загальної чисельності населення. За національним демографічним прогнозом до 2025 р. відбудуться зміни у віковому складі населення України. Особи понад 60 років складатимуть $25 \%$, понад 65 років - 18,4 \% населення, а в 2030 році кількісні показники літніх осіб зростуть відповідно на 1-2 \% [4]. Ця демографічна тенденція частково зумовлена специфікою способу життя та соціально-економічним становищем літніх людей та поглиблює проблеми соціального й економічного розвитку.

3 віком ціла низка екзо- та ендогенних чинників зумовлює мікроструктурні метаболічні порушення кісткової тканини, зниження кісткової маси та розвиток остеопорозу [1-3, 5-7]. Значна втрата маси кісткової тканини та погіршення їі мікроархітектоніки суттєво впливають на виник- нення дегенеративно-дистрофічних захворювань опорно-рухового апарату та низькоенергетичних переломів кісток [1-3, 5]. Доведено зв'язок між показниками мінеральної щільності кісткової тканини (МЩКТ) та ризиком виникнення остеопоротичних переломів, зокрема переломів тіл хребців, переломів проксимального відділу стегнової кістки (ПВСК), плечової кістки, кісток передпліччя [5-12]. Особливо на цьому наголошують науковці "Інституту геронтології імені Д. Ф. Чеботарьова НАМН України”, які достовірно довели залежність кількісних показників виникнення переломів стегнової кістки у хворих із порушеннями МЩКТ $[6,8,12]$. Для можливої корекції цих порушень важливим $€$ визначення базових (вихідних) показників структурно-функціонального стану кісткової тканини (СФСКТ) у людей літнього віку, які складають основну групу ризику виникнення переломів. Доречним $€$ і виявлення аналогічних змін у хворих після перелому з метою оптимізації процесу репаративної регенерації кісткової тканини [3, 8].

Мета роботи: проаналізувати СФСКТ у людей похилого та старечого віку та структуру переломів вертлюгової ділянки стегнової кістки (ВДСК) на грунті порушень МЩКТ. 
Матеріали і методи. Провели ретроспективне обстеження 98 хворих віком від 60 до 90 років, які перебували на лікуванні в КНП “Івано-Франківська обласна клінічна лікарня Івано-Франківської обласної ради” впродовж 2008-2018 рр. Дві групи спостереження склали 46 хворих із переломами ВДСК - I (основна) група, які отримали низькоенергетичні пошкодження при падінні. Середній вік хворих склав $(75,4 \pm 10,8)$ року. До контрольної групи увійшли 52 осіб аналогічних за віком, котрі звертались на обстеження з приводу захворювань опорно-рухового апарату. Загалом більшість (89 хворих) склали особи жіночої статі, чоловічної статі -9 .

Для визначення структурно-функціонального стану кісткової тканини та діагностики остеопорозу усім хворим виконали двохенергетичну рентгенівську абсорбціометрію (DEXA) поперекового відділу хребта за допомогою апарата CHALLENGER MULTISITI DEXA SCANNER - залишається золотим стандартом для визначення МЩКТ шийки стегнової кістки, хребта й всього скелета [2, 3]. У хворих I групи перед оперативним втручанням встановили тип перелому за класифікацією AO/ASIF, а на 4-5 день після остеосинтезу виконали одночасно контрольне рентгенообстеження та денситометрію.

У кожній групі хворих визначили частку осіб похилого (від 60 до 74 років) та старечого (75 - 90 років) віку. Розподіл наведено в таблиці 1.

До моменту обстеження хворі не отримували остеотропних медикаментозних препаратів.

Таблиця 1. Кількісний розподіл хворих за віком у групах спостереження

\begin{tabular}{||c|c|c||}
\hline \multirow{2}{*}{ Група дослідження } & \multicolumn{2}{|c|}{ Кількість хворих, абс. ( \%) } \\
\cline { 2 - 3 } & похилого віку $(60-74$ років) & Старечого віку $(75-90$ років) \\
\hline I & $15(32,6)$ & $31(67,4)$ \\
\hline II & $36(69,2)$ & $16(30,7)$ \\
\hline
\end{tabular}

Результати досліджень та їх обговорення. За результатами денситометрії у хворих похилого та старечого віку структурні порушення кісткової тканини виявлено у 72 (73,5 \%) обстежених. Серед хворих I групи похилого віку за структурою МЩКТ, що відповідала віковій нормі, було 5 (33,3 \%) пацієнтів, з явищами остеопенії - 7 (46,7 \%), остеопорозу - 3 (20,0 \%). Середній показник Т-індексу хворих похилого віку становив - -1,32 (81,02 \%). Серед хворих старечого віку I групи МЩКТ, що відповідала віковій нормі, діагностовано у 1 (3,2 \%) пацієнта, остеопенії - 18 (58,1 \%), остеопорозу - 12
(38,7 \%) (рис. 1). Середній показник Т-індексу становив - -1,86 (76,04 \%), а максимальний показник зниження кісткової маси - T= -3,5 (54 \%).

Серед хворих II групи похилого віку було 36 пацієнтів. МЩКТ, що відповідала віковій нормі, діагностовано у $16(44,4 \%)$ пацієнтів, остеопенія - 19 (52,8 \%), остеопороз - 1 (2,8 \%). Середній показник Т-індексу становив -0,85(88,58 \%). Серед 16 хворих старечого віку II групи за структурою МЩКТ, що відповідала віковій нормі, було 4 (25,0 \%) пацієнтів, з явищами остеопенії - 10 (62,5 \%), остеопорозу - 2 (12,5 \%) (рис. 2). Середній показник

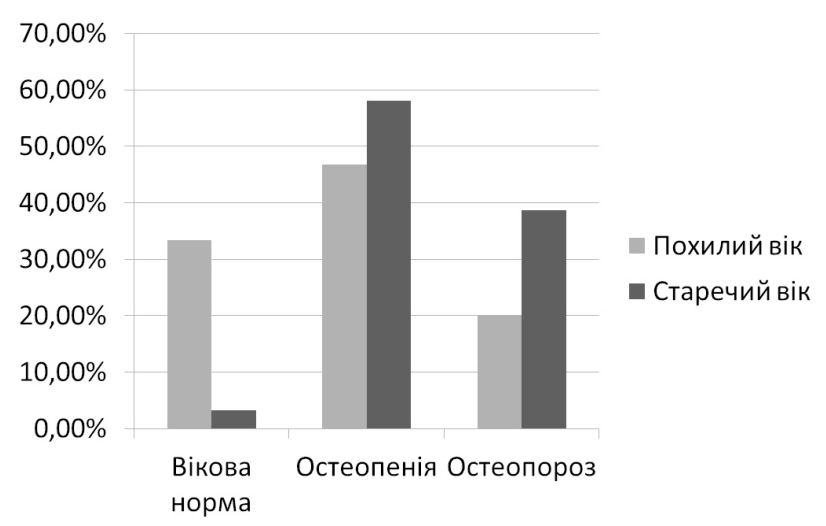

Рис. 1. Розподіл хворих I групи за даними денситометрії.

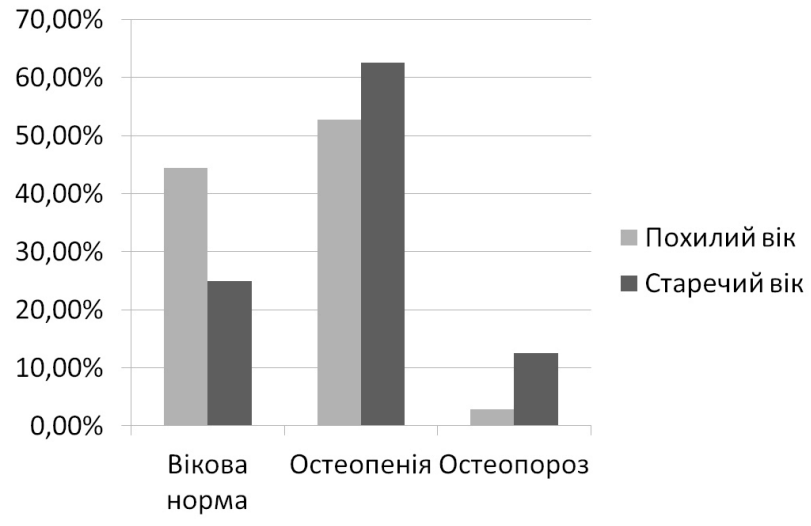

Рис. 2. Розподіл хворих II групи за даними денситометрії. 
Т-індексу становив -1,33(82,37 \%), а максимальний показник зниження кісткової маси - T=-2,8 (64 \%).

За рентгенограмами ПВСК у хворих I групи з переломами цієї ділянки визначено тип перелому за класифікацією AO/ASIF. Важливо зазначити, що як у 4 хворих похилого віку, так і в однієї хворої старечого віку, в яких на денситометрії виявлено вікову норму, переломи ВДСК визначали як прості: A1.1, А2.1, А3.1 і становив 5 (10,9 \%) випадків. В однієї хворої похилого віку з показником денситометрії, що відповідав віковій нормі був перелом типу А2.2 (2,2 \%).

Серед хворих, у яких за даними денситометрій виявили ознаки остеопенії та остеопорозу, переломи за класифікацією AO/ASIF розподілилися наступним чином (рис. 3) та (рис. 4) відповідно.
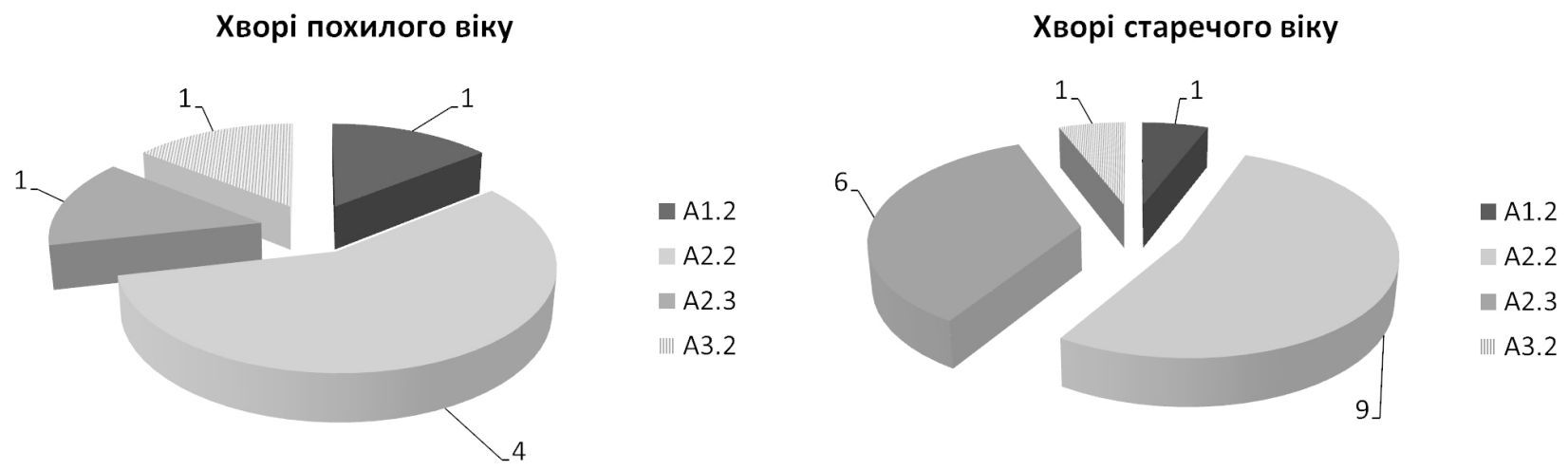

Рис. 3. Розподіл хворих з остеопенією та переломом ВДСК за класифікацією AO/ASIF.

Хворі похилого віку

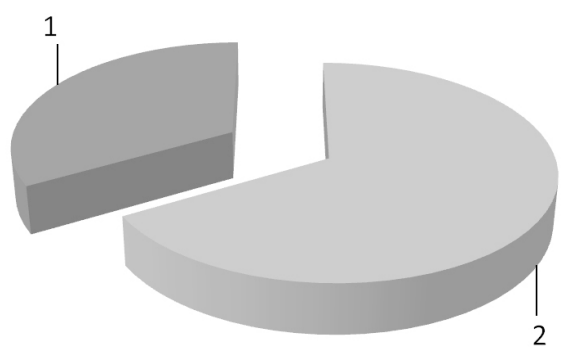

Хворі старечого віку

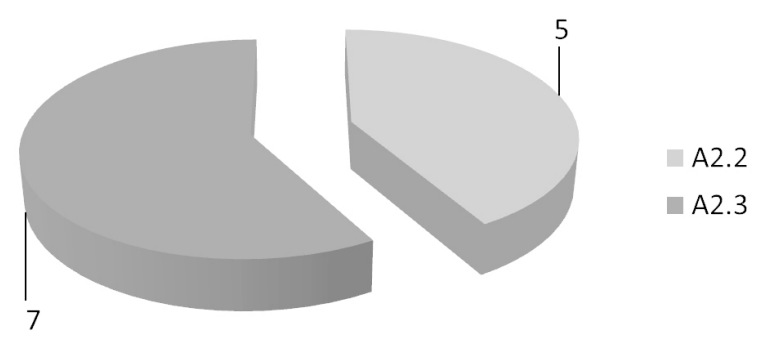

Рис. 4. Розподіл хворих з остеопорозом та переломом ВДСК за класифікацією AO/ASIF.

Важливо зазначити, що найбільша частина хворих із двох вікових груп отримали переломи типу А2.2, що становить 21(45,7 \%) випадків, діагностовано в найбільшій кількості серед хворих похилого та старечого віку з остеопенією та у хворих похилого віку з остеопорозом. Серед хворих старечого віку з остеопорозом більшу частину переломів вертлюгової ділянки становив тип А2.3 7 (15,2 \%) випадків.

За результатами проведених обстежень хворих важливо виділити деякі особливості. Низькі показники МЩКТ на денситометрії свідчать про суттєве порушення ії СФСКТ у 42 (91,3 \%) у хворих I групи. Середнє значення Т індексу низьке у даної групи хворих і становить - $-1,59$, що у відсотках залишку кісткової маси становить 78,53 \%.
У хворих II групи порушення СФСКТ виявлено у 32 (61,5 \%) пацієнтів цієї вікової категорії. Середнє значення $\mathrm{T}$ індексу вище у даної групи хворих і становить $-1,09$ (86,6 \%). У хворих, в яких при денситометрії виявлено порушення структури кісткової тканини, переломи здебільшого були складні, тобто уламкові зі зміщенням, і становили 39 (84,8 \%) випадків.

Висновки. Порушення показників МЩКТ в обстежених нами хворих похилого та старечого віку та висока частота складних уламкових переломів вказують на необхідність подальшого вивчення СФСКТ та оптимізації лікування у хворих цієї вікової категорії. 


\section{З ДОСВІДУ РОБОТИ}

\section{СПИСОК ЛІТЕРАТУРИ}

1. Корж Н. А. Профилактика остеопороза и остеопоротических переломов / Н. А. Корж, Н. В. Дедух // Ортопедия, травматология и протезирование - 2010. - № 3. - С. 120-124.

2. Поворознюк В. В. Ультразвукова денситометрія в оцінці структурно-функціонального стану кісткової тканини / В. В. Поворознюк, Н. В. Григор'єва, Вас. В. Поворознюк // Біль. Суглоби. Хребет. - 2013. - 4 (12) - С. 5-12.

3. Остеопороз в практике врача-интерниста / В. В. Поворознюк, Н. В. Григорьєва, Т. В. Орлик [и др.]. - К., 2014. - 198 с. 4. Україна - серед світових лідерів за темпами “старіння" населення [Електронний ресурс] / Укрінформ. URL: https:// www.ukrinform.ua/rubric-society/2391914.

5. Сулима В. С. Проблеми хірургічного лікування хворих літнього віку з переломами проксимальної частини стегнової кістки / В. С. Сулима // Боль. Суставы. Позвоночник. - 2011. - № 3. - C. 3-14.

6. Population trends in BMD testing, treatment, and hip and wrist fracture rates: are the hip fracture projections wrong?/ S. B. Jaglal, I. Weller, M. Mamdani [et al.] // J. Bone Miner. Res. - 2005. Vol. 20 (6). - 898-905.

7. Osteoporosis as a risk factor for distal radial fractures: a casecontrol study / J. Oyen, C. Brudvik, C. G. Gjesdal [et al.] //

\section{REFERENCES}

1. Korzh, N.A., \& Dedukh, N.V. (2010). Profilaktika osteoporoza i osteoporoticheskikh perelomov [Prevention of osteoporosis and osteoporotic fractures]. Ortopediya, travmatologiya i protezirovanie - Orthopedics, Traumatology and Prosthetics, 3, 120124 [in Russian].

2. Povorozniuk, V.V., Hrygorieva, N.V., \& Povorozniuk, V.V. (2013). Ultrazvukova densytometriia v otsintsi strukturno-funktsionalnogo stanu kistkovoi tkanyny [Ultrasonic densitometry in the assessment of the structural and functional state of bone tissue]. Bil. sugloby khrebet - Pain. Joints. Spine, 4 (12), 5-12 [in Ukrainian].

3. Povorozniuk, V.V., Hrigoreva, N.V., \& Orlik, T.V. (2014). Osteoporoz $v$ praktike vracha-internista [Osteoporosis in the practice of an internist]. Kyiv [in Russian].

4. Ukraina sered svitovykh lideriv za tempamy "starinnia" naselennia. Ukrinform [Ukraine is among the world leaders in the rate of "aging" of the population. Ukrinform]. Retrieved from https:// www.ukrinform.ua/rubric-society/2391914/ [in Ukrainian].

5. Sulyma, V.S. (2011). Problemy khirurhichnoho likuvannia khvorykh litnoho viku z perelomamy proksymalnoi chastyny stehnovoi kistky [Problems of surgical treatment of elderly patients with fractures of the proximal femur]. Bol. sustavy i pozvonochnik - Pain Joints Spine, 3, 3-14 [in Ukrainian].

6. Jaglal, S.B., Weller, I., Mamdani, M. Hawker, G., Kreder, H., Jaakkimainen, L. et. al. (2005). Population trends in BMD testing, treatment, and hip and wrist fracture rates: are the hip fracture projections wrong? J. Bone Miner. Res., 20 (6), 898-905.

7. Oyen, J., Brudvik, C., Gjesdal, C.G., Tell, G.S, Lie, S.A., \& Hove, L.M. (2011). Osteoporosis as a risk factor for distal radi-
J. Bone Joint Surg. Am. - 2011. - Vol. 93 (4). - P. 348-356.

8. Григор'єва Н. В. Мінеральна щільність кісткової тканини та рівень вітаміну D у хворих різного віку з переломами кісток нижніх кінцівок різної локалізації (огляд літератури та результати власних досліджень) / Н. В. Григор’єва, Р. О. Власенко, О. Б. Зубач, В.В. Поворознюк // Травма. - 2017. - 18 (6) - С. 8-18.

9. Побел $Є$. А. Перелом - фактор ризику розвитку остеопенії та остеопорозу / Є. А. Побел, Н. В. Дедух // Травма. - 2012. T. 13, № 4. - C. 49-51.

10. Сучасні принципи діагностики та лікування захворювань кістково-м’язової системи в людей різного віку / За ред. В. В. Поворознюка. - Київ : Карбон-сервіс, 2008. - 220 с.

11 . The association between dietary inflammatory properties and bone mineral density and risk of fracture in US adults / M. Mazidi, N. Shivappa, M. D. Wirth [et al.] // Eur. J. Clin. Nutr. - 2017. Vol. 71 (11). - P. 1273-1277.

12. Osteoporotic Fractures Research Group BMD at multiple sites and risk of fracture of multiple types: long-term results from the Study of Osteoporotic Fractures / K. L. Stone, D. G. Seeley, L.Y. Lui // J. Bone Miner. Res. - 2003. - Vol. 18 (11). - P. 1947 1954.

al fractures: a case-control study. J Bone Joint Surg. Am., 93 (4), 348-356.

8. Hryhorieva, N.V., Vlasenko, R.O., Zubach, O.B., \& Povorozniuk, V.V. (2017). Mineralna shchilnist kistkovoi tkanyny ta riven vitaminu D u khvorykh riznoho viku z perelomamy kistok nyzhnikh kintsivok riznoi lokalizatsii (ohliad literatury ta rezultaty vlasnykh doslidzhen) [Bone mineral density and vitamin D level in persons of different ages with lower limb fractures (literature review and results of own researches)]. Travma - Trauma, 18 (6), 8-18 [in Ukrainian].

9. Pobel, Ye.A., \& Dedukh, N.V. (2012). Perelom - faktor ryzyku rozvytku osteopenii ta osteoporozu [Fracture is a risk factor for osteopenia and osteoporosis]. Travma - Trauma, 13 (4), 4951 [in Ukrainian].

10. Povorozniuk, V.V. (2008). Suchasni pryntsypy diahnostyky ta likuvannia zakhvoriuvan kistkovo-miazovoi systemy $v$ liudei riznoho viku [Modern principles of diagnosis and treatment of diseases of the musculoskeletal system in people of all ages]. Kyiv: Karbon-servis [in Ukrainian].

11. Mazidi, M., Shivappa, N., Wirth, M. D., Hebert, J.R., Vatanparast, H., \& Kengne, A. P. (2017). The association between dietary inflammatory properties and bone mineral density and risk of fracture in US adults. Eur. J. Clin. Nutr., 71 (11), 1273-1277. 12. Stone, K.L., Seeley, D.G., Lui, L.Y., Cauley, J.A., Ensrud, K., Browner, W.S. et al. (2003). Osteoporotic Fractures Research Group BMD at multiple sites and risk of fracture of multiple types: long-term results from the Study of Osteoporotic Fractures. J. Bone Miner. Res., 18 (11), 1947-1954.

Отримано 26.08.2020 
Y. D. VALOVINA, Z. Y. VITVITSKY, N. Y. VALOVINA

Ivano-Frankivsk National Medical University

\title{
CHARACTERISTICS OF THE STRUCTURAL AND FUNCTIONAL STATE OF BONE TISSUE IN ELDERLY AND SENILE PATIENTS WITH FEMUR ACETABULUM FRACTURES
}

\begin{abstract}
The aim of the work: to analyze the structural and functional state of bone tissue (SFSBT) in the elderly and senile patients and the structure of the acetabulum fractures of the femur due to violations in bone mineral density (BMD).

Materials and Methods. The paper analyzes the results of the examination of 98 elderly and senile patients who were treated at the Ivano-Frankivsk Regional Clinical Hospital of the Ivano-Frankivsk Regional Council during 2008-2018. The mean age of the patients was (75.4 \pm 10.8 ) (60 to 90 years). The group consisted of 46 patients with acetabulum fractures of the femur (main group), they received low-energy injuries. The control group included 52 people who were examined for diseases of the musculoskeletal system. All patients underwent dual-energy x-ray absorptiometry (DEXA) of the lumbar spine. In patients of group I, the type of fracture was determined according to the AO/ASIF classification.

Results and Discussion. Violations of BMD were found in 72 (73.5 \%) patients in both groups. In group I the maximum decrease rate in bone mass $\mathrm{T}$ index was -3.5 , in group II $-\mathrm{T}=-2.8$. In elderly patients of group $\mathrm{I}$, the average $\mathrm{T}$ index was -1.32 , and in senile patients of group I - -1.86. In elderly patients of group II, the average T was -0.85 , and in senile patients of group II - -1.33 . Among group I patients, in whom densitometry revealed violations in bone structure, according to the classification of AO/ASIF, most fractures were complex, i.e., fragmentary with displacement, and amounted to 39 (84.8\%) cases.

The elderly and senile patients examined by us revealed that the violations in BMD and the high frequency of complex multifragmentary fractures indicate the necessity in further SFSBT study as well as optimization of treatment in patients of this age category.
\end{abstract}

Key words: bone mineral density; acetabulum fracture of the femur; structural and functional state of bone tissue.

\section{Ю. Д. ВАЛОВИНА, З. Я. ВИТВИЦКИЙ, Н. Ю. ВАЛОВИНА}

Ивано-Франковский национальный медицинский университет

\section{ХАРАКТЕРИСТИКА СТРУКТУРНО-ФУНКЦИОНАЛЬНОГО СОСТОЯНИЯ КОСТНОЙ ТКАНИ У БОЛЬНЫХ ПОЖИЛОГО И СТАРЧЕСКОГО ВОЗРАСТА С ПЕРЕЛОМАМИ ВЕРТЕЛЬНОЙ ОБЛАСТИ БЕДРЕННОЙ КОСТИ}

\begin{abstract}
Цель работы: проанализировать структурно-функциональное состояние костной ткани (СФСКТ) у людей пожилого и старческого возраста и структуру переломов вертельной области бедренной кости (ВОБК) на почве нарушений минеральной плотности костной ткани (МПКТ).

Материалы и методы. В работе проанализированы результаты обследования 98 больных пожилого и старческого возраста, находившихся на лечении в КНП “Ивано-Франковская областная клиническая больница Ивано-Франковского областного совета” в течение 2008-2018 гг. Средний возраст больных составлял 75,4 + 10,8 (от 60 до 90 лет). I группу составили 46 больных с переломами ВОБК (основная группа), которые получили низкоэнергетические повреждения. В контрольную группу вошли 52 человека, которые обследовались по поводу заболеваний опорно-двигательного аппарата. Всем больным выполнена двухэнергетическая рентгеновская абсорбциометрия (DEXA) поясничного отдела позвоночника. У больных I группы определяли тип перелома по классификации AO/ASIF.

Результаты исследований и их обсуждение. Нарушение показателей МПКТ выявлено у 72 (73,5 \%) больных обеих групп. У больных I группы максимальный показатель снижения костной массы Т индекс составлял $-3,5$, у больных II группы - T = -2,8. У больных пожилого возраста I группы средний показатель Т индекса составил -1,32, а у больных старческого возраста I группы - -1,86. У больных пожилого возраста II группы средний показатель Т составил $-0,85$, а у больных старческого возраста II группы - -1,33. Среди больных I группы, в которых при денситометрии выявлены нарушения структуры костной ткани, большинство переломов по классификации AO/ASIF были сложными, то есть осколочные со смещением, и составили 39 (84,8 \%) случаев. Нарушение показателей МПКТ у обследованных больных пожилого и старческого возраста и высокая частота сложных осколочных переломов указывают на необходимость дальнейшего изучения СФСКТ и оптимизации лечения у больных этой возрастной категории.
\end{abstract}

Ключевые слова: минеральная плотность костной ткани; перелом вертельной области бедренной кости; структурно-функциональное состояние костной ткани. 